\title{
Pendidikan dalam Paket Wisata Kampung Kreatif Kota Blitar (Studi Fenomenologi Terhadap Kampung Kreatif di Kota Blitar)
}

\author{
Maria Ulfa Yudha Julistiyana ${ }^{\mathrm{a}, 1, *}$ \\ ${ }^{a}$ Fakultas Keguruan dan Ilmu Pendidikan, Universitas Islam Balitar, Indonesia \\ ${ }^{1}$ mariaulfayudha90@gmail.com
}

ARTICLE INFO (8 pt)

Article history:

Submitted: May 19, 2020

Reviewed: June 3, 2020

Accepted: June 16, 2020

Published: June 30, 2020

Keywords: Education, Tour Packages, Creative Villages, Blitar City

Kata kunci: Pendidikan, Paket Wisata, Kampung Kreatif, Kota Blitar

\section{ABSTRACT (10PT)}

The purpose of this study is to describe the role of education in determining the creative village tour packages that are starting to actively develop in Blitar City. The role of education does not escape the needs of tourists when doing tourism activities. The support of the tourism office to empower creative villages in Blitar City is due to the "MAYA JUWITA" program (Community Empowered Towards Tourism City) between the City of Blitar. Qualitative research in this study provides its natural role, namely to seek understanding, and interpretation in the form of interpretations of phenomena seen by researchers through the Blitar City culture and tourism service in the creative village related to educational tourism packages. Qualitative implementation in this study uses a phenomenological approach where researchers analyze using descriptive analysis techniques about the phenomena that occur in creative villages in Blitar City. These results indicate research into the role of education in determining tour packages to make creative villages find positive impacts that are quite good. In fact $80 \%$ of the survey results of several creative villages there are 8 out of 10 creative villages in the City of Blitar including education packages that are the mainstay to provide economic opportunities for residents around the village.

\section{ABSTRAK}

Tujuan penelitian ini adalah Untuk mendeskripsikan peran pendidikan pada penentuan paket wisata kampung kreatif yang mulai aktif berkembang di Kota Blitar. Peran pendidikan tidak luput dari kebutuhan wisatawan saat melakukan kegiatan pariwisata. Adanya dukungan dinas pariwisata untuk memberdayakan kampung kreatif di Kota Blitar tak lain karena program "MAYA JUWITA" (Masyarakat Berdaya Menuju Kota Pariwisata) antar Kota Blitar. Penelitian kualitatif dalam penelitian ini memberikan peran alaminya yaitu untuk mencari pemahaman, dan interpretasi berupa tafsiran fenomena yang dilihat peneliti melalui dinas kebudayaan dan pariwisata Kota Blitar pada kampung kreatif terkait tentang paket wisata edukasi. Implementasi kualitatif pada penelitian ini menggunakan pendekatan fenomenologi dimana peneliti menganalisis menggunakan teknik analisis deskriptif tentang fenomena yang terjadi pada Kampung kreatif di Kota Blitar. Hasil tersebut menunjukan penelitian peran pendidikan dalam penentuan paket wisata menjadikan kampung kreatif menemukan dampak positif yang cukup baik. Faktanya $80 \%$ hasil survey beberapa kampung kreatif ada 8 dari 10 kampung kreatif di Kota Blitar menyertakan paket edukasi yang menjadi andalan untuk memberikan peluang peningkatan ekonomi warga sekitar kampung. 


\section{Pendahuluan}

Perkembangan pariwisata di Indonesia sedang menjadi sorotan dunia. Beberapa prestasi ditorehkan Indonesia pada ajang International. Penghargaan yang membanggakan salah satunya yaitu berhasil meraih dalam bidang inovasi wisata internasional dari United Nation World Tourism Organization (UNWTO) atau Organisasi Pariwisata Dunia PBB di Madrid Spanyol. Alasan perkembangan pariwisata Indonesia ini didukung pula oleh keanekaragaman budaya dan adat istiadat Nusantara.

Keanekaragaman budaya Indonesia membawa pariwisata semakin mudah menemukan kreativitas dan inovasi dalam mengembangkan potensi yang ada. Masingmasing daerah memberikan nuansa khas yang tidak hanya budaya yang menarik tapi juga keramah-tamahan penduduknya. Kota Blitar merupakan salah satu kota di Provinsi Jawa Timur Indonesia yang memiliki keanekaragaman budaya dan potensi perkembangan inovasi dibidang pariwisata. Selain itu untuk mendukung Program Pemkot Blitar yaitu "MAYA JUWITA" (Masyarakat Berdaya Menuju Kota Pariwisata) antar Kota Blitar. Maka memaksimalkan potensi yang dimiliki setiap kelurahan di Kota Blitar adalah upaya mewujudkan "Maya Juwita". Pada tahun 2019 program tersebut juga mendapatkan prestasi membanggakan dari Gubernur Jawa Timur yaitu Penghargaan Pembangunan Daerah (PPD) 2019 untuk kategori kota.

Pengembangan Program "Maya Juwita" berhasil memunculkan kampungkampung kreatif dan inovatif yang kemudian menjadi program Dinas Kebudayaan dan Pariwisata untuk memfasilitasi perkembangan keberadaannya. Dimulai dengan perlombaaan perencanaan sampai membentuk sebuah kampung yang lengkap dengan paket-paket wisata.

Paket wisata pada kampung kreatif kota blitar memberikan harapan baru pada warga atau penduduk sekitar untuk menambah pemasukan desa maupun pribadi. Namun ada hal menarik dimana pada kampung-kampung kreatif ini memberikan konsep pendidikan / edukasi pada paket wisata yang ditawarkan pada wisatawan. Seperti yang diutarakan
Sonya amalia, wisata edukasi ini dapat dimanfaatkan oleh sekolah atau instansi pendidikan lainnya sebagai salah satu acuan pembelajaran di luar lingkungan sekolah. Sehingga memberikan public image bahwa kampung kreatif adalah kampung edukasi yang memberikan manfaat sebagai sumber ilmu pengetahuan selain hanya untuk sarana bersenang-senang.

\section{Review Tinjauan Pustaka}

\section{A. PENGERTIAN PARIWISATA}

Menurut Clare dan Edward (2002, 1991) pariwisata merupakan kegiatan yang dilakukan seseorang ke suatu perjalanan diluar kesehariannya. Dimana perjalanan ini memiliki tujuan bersenang-senang dan bersifat sementara, tanpa bermaksud untuk mencari nafkah. Selain itu juga untuk mendapatkan pengalaman perjalanan dan pelayanan di sebuah tempat tinggal yang memiliki fasilitas terbaik.

\section{B. JENIS-JENIS PARIWISATA}

Jenis dan macam Pariwisata/ Kepariwisataan tidak dapat didefinisikan secara tunggal. Secara umum hal itu dijelaskan sebagai kegiatan yang dilakukan seseorang ke suatu perjalanan diluar kesehariannya serta untuk keperluan perencanaan dan pengembangan kepariwisataan itu sendiri. Perbedaan antara pariwisata dengan jenis pariwisata sangat diperlukan sehingga jenis dan macam pariwisata yang dikembangkan dapat tercipta. Menurut Suwena dan Widyatmaja (2017) dalam bukunya yang berjudul "Pengetahuan Dasar Ilmu Pariwisata" jenis-jenis pariwisata antara lain, misalnya :

1. Menurut letak geografis, kegiatan pariwisata dibedakan menjadi :

a) Pariwisata lokal (local tourism) yaitu jenis kepariwisataan yang lokasinya lebih sempit untuk melakukan kegiatan pariwisata. Contohnya : Pariwisata Kota Blitar, Pariwisata Kota Denpasar.

b) Pariwisata regional (regional tourism) adalah jenis kepariwisataan yang lebih fokus dalam lokasi eksklusif missal regional, dalam area nasional maupun regional dalam area International. 
Contohnya: kepariwisataan Bali dan kepariwisataan Yogyakarta

c) Pariwisata nasional (national tourism) adalah jenis kepariwisataan yang lebih fokus dalam lokasi wilayah suatu negara, dimana wisatawan pengunjung tidak hanya berasal dari warga negaranya sendiri namun juga wisatawan asing yang tinggal di Negara tersebut.

d) Pariwisata regional-internasional jenis kepariwisataan yang lokasinya berupa wilayah internasional yang terbatas, tetapi melewati batas lebih dari dua atau tiga negara dalam wilayah tersebut. Contohnya: kepariwisataan ASEAN.

e) Pariwisata internasional (International tourism) jenis kepariwisataan yang wilayah kegiatan kepariwisataan berkembang di beberapa negara di dunia. Contohnya: Disneyland

2. Menurut pengaruhnya terhadap neraca pembayaran:

a) Pariwisata aktif (in bound tourism) adalah jenis kepariwisataan yang memiliki kegiatan ditandai dengan alasan masuknya wisatawan asing ke suatu negara. Secara langsung perihal ini akan menambah pendapatan devisa bagi negara yang dikunjungi. Secara otomatis akan memperkuat kondisi neraca pembayaran negara yang dikunjungi wisatawan tersebut.

b) Pariwisata pasif (out-going tourism) adalah jenis kepariwisataan yang memiliki kegiatan ditandai dengan gejala keluarnya warga negara sendiri melakukan perjalanan ke luar negeri sebagai wisatawan. Sebab ditilik dari pemasukan devisa negara, perjalanan wisata ini dapat merugikan negara asal wisatawan, karena uang yang dipergunakan itu terjadi transakasi di luar Negara asal.

\section{Menurut alasan/tujuan perjalanan :}

a) Business tourism adalah jenis pariwisata dimana pengunjung memiliki alasan datang untuk tujuan dinas atau bekerja, berdagang, kongres, seminar dan lain-lain.

b) Vacational tourism adalah jenis pariwisata dimana pengunjung memiliki alasan melakukan perjalanan wisata terdiri dari wisatawan yang sedang ingin liburan, cuti, dan lain-lain

c) Educational tourism adalah jenis pariwisata dimana pengunjung memiliki alasan melakukan perjalanan untuk tujuan edukasi atau mempelajari suatu ilmu pengetahuan. Contohnya : darmawisata/ study tour.

d) Familiarization tourism adalah jenis pariwisata dimana pengunjung memiliki alasan kunjungan yang dimaksudkan guna mengenal lebih lanjut daerah yang mempunyai kaitan dengan pekerjaannya. Contohnya : Studi Banding

e) Scientific tourism adalah jenis pariwisata dimana pengunjung memiliki alasan untuk memperoleh pengetahuan atau penyelidikan terhadap sesuatu bidang kajian ilmu pengetahuan.

f) Special Mission tourism adalah jenis pariwisata dimana pengunjung memiliki alasan khusus, misalnya misi kesenian (mencari inspirasi), misi olah raga (latihan untuk tournament), maupun misi lainnya.

g) Hunting tourism adalah jenis pariwisata dimana pengunjung memiliki alasan untuk menyelenggarakan perburuan binatang yang diijinkan oleh pengelola daerah setempat sebagai hiburan dan mengisi waktu liburan.

\section{Menurut saat atau waktu berkunjung :}

a) Seasonal tourism adalah jenis pariwisata yang kegiatannya berlangsung pada waktu tertentu. Contoh : liburan musim pnas, liburan musim dingin.

b) Occasional tourism adalah jenis pariwisata yang kegiatannya berlangsung dengan kejadian (occasion) atau peristiwa penting maupun suatu even. Misalnya Acara Sekaten di Yogyakarta, Budaya Nyepi di Bali, dan lain-lain.

\section{Menurut Objeknya :}

a) Cultural tourism adalah jenis kepariwisataan yang memiliki keinginan dari wisatawan dikarenakan ketertarikan nakan seni dan budaya suatu daerah.

b) Recuperational tourism adalah jenis kepariwisataan yang memiliki keinginan dari wisatawan untuk menyembuhkan penyakit dan terapi tertentu. Contohnya: mandi di sumber pemandian air panas. 
c) Commercial tourism adalah jenis kepariwisataan yang memiliki keinginan dari wisatawan dikarenakan melakukan perjalanan untuk melakukan perdagangan nasional dan internasional.

d) Sport tourism adalah jenis kepariwisataan yang memiliki keinginan dari wisatawan dikarenakan untuk menikmati sebuah pertandingan olah raga di daerah atau Negara tertentu. Contohnya: menonton balapan Moto GP.

e) Political tourism adalah jenis kepariwisataan yang memiliki keinginan dari wisatawan dikarenakan menyaksikan suatu momen/peristiwa penting sebuah Negara. Contohnya: Menyaksikan peringatan kemerdekaan sebuah Negara.

f) Social tourism adalah jenis kepariwisataan yang memiliki keinginan dari wisatawan dikarenakan pengelola kegiatan tidak mengambil keuntungan. Ontohnya study tour atau picnic.

g) Religion tourism yaitu adalah jenis kepariwisataan yang memiliki keinginan dari wisatawan dikarenakan keinginan menyaksikan acara keagamaan suatu daerah. Contohnya: Ngaben di Bali, Umroh di Saudi.

h) Marine tourism adalah jenis kepariwisataan yang memiliki keinginan dari wisatawan dikarenakan kegiatan wisata ditunjang beberapa fasilitas yang menarik. Missal sarana untuk menyelam, memancing, berenang, dan olah raga lainnya, termasuk pelayanan akomodasi, kuliner.

6. Menurut jumlah orang yang melakukan perjalanan

a) Individual tourism adalah jenis kepariwisataan yang dilakukan oleh wisatawan peroarangan atau bersama satu keluarga bersama. Dimana perjalanan dilakukan bersama-sama.

b) Family group tourism adalah jenis kepariwisataan yang dilakukan oleh wisatawan rombongan beberapa keluarga yang memiliki hubungan kekerabatan satu dengan lainnya.

c) Group tourism adalah jenis kepariwisataan yang dilakukan oleh wisatawan yang dari banyak orang kemudian bergabung dalam sebuah rombongan perjalanan wisata.
Biasanya dilakukan oleh organisasi, sekolah, ataupun agen tour travel.

7. Menurut alat pengangkutan yang digunakan :

a) Land tourism adalah jenis kepariwisataan yang dalam proses perjalanannya menumpangi kendaraan darat. Contohnya : Bus, Taxi, Mobil dan lain sebagainya.

b) Sea tourism adalah jenis kepariwisataan yang dalam proses perjalanannya menumpangi kendaraan yang beroperasi di laut/air untuk mengunjungi suatu tempat/daerah wisata.

c) Air tourism adalah jenis kepariwisataan yang dalam proses perjalanannya menumpangi kendaraan yang beroperasi di udara untuk menuju daerah wisata.

8. Menurut umur yang melakukan perjalanan:

a) Youth tourism adalah jenis kepariwisataan yang disuguhkan untuk para remaja yang menyukai perjalanan wisata dengan harga ekonomis.

b) Abdult tourism adalah jenis kepariwisataan yang disuguhkan untuk orang lanjut usia yang membutuhkan area untuk melepaskan kebosanan.

\section{Menurut harga dan tingkat social:}

a) Delux tourism adalah jenis kepariwisataan yang menggunakan sarana prasarana kualitas standar mewah, misalanya alat angkutan, penginapan, dan paket wisatanya.

b) Middle class tourism adalah jenis kepariwisataan yang menggunakan sarana prasarana untuk wisatawan yang menginginkan fasilitas dengan harga yang tidak terlalu mahal dan memiliki pelayanan terbaik.

c) Social tourism adalah jenis kepariwisataan yang menggunakan sarana prasarana yang dilakukan secara bersamasama dengan rincian biaya semurah mungkin sehingga mereka dapat menikmati fasilitas yang memadai.

\section{KOMPONEN PARIWISATA DALAM KEGIATAN PARIWISATA}


Komponen pariwisata sangat berkaitan dalam proses pengembangan sebuah kawasan wisata. Oka Yoeti (1996) berpendapat komponen pariwisata dibagi atas dua aspek, yaitu komponen permintaan (demand) dalam pariwisata dan komponen penawaran (supply) dalam pariwisata. Penawaran pariwisata meliputi semua hal yang ditawarkan kepada wisatawan seperti akomodasi, infrastruktur, paket wisata, atraksi wisata, transportasi, dan fasilitas pendukung lainnya. Sedangkan permintaan atau demand pariwisata adalah segala semua hal yang berhubungan dengan permintaan pariwisata dari pengunjung dan masyarakat. Permintaan dapat bertahap sebagai evaluasi lokasi pariwisata.

\section{PENGERTIAN KAMPUNG WISATA}

Desa/Kampung Wisata yaitu suatu wilayah perkampungan padat penduduk yang menawarkan originalitas kampung baik dari segi sosial budaya, adat- istiadat, keseharian, arsitektur tradisional, struktur tata ruang kampung yang disajikan dalam bentuk integrasi komponen pariwisata antara lain seperti variasi paket wisata, atraksi, akomodasi dan fasilitas pendukung. (Darsono, 2005)

\section{Metodologi Penelitian}

Penelitian kualitatif dalam penelitian ini memberikan peran alaminya yaitu untuk mencari pemahaman, dan interpretasi berupa tafsiran pada fenomena yang dilihat dinas kebudayaan dan pariwisata Kota Blitar dan kampung kreatif terkait tentang paket wisata edukasi kepada peneliti. Implementasi kualitatif pada penelitian ini menggunakan pendekatan fenomenologi dimana peneliti menganalisis menggunakan teknik analisis deskriptif tentang fenomena yang terjadi pada Kampung kreatif di Kota Blitar. Fenomena tersebut yang kemudian kita analisis.

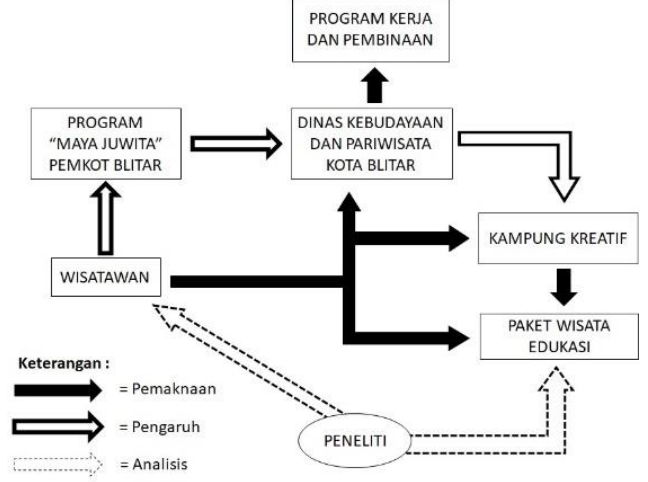

Gambar 1. Hasil Olahan Peneliti

\section{Pembahasan}

\section{Kebutuhan Pariwisata Kota Blitar}

Robert menyatakan pariwasata merupakan kegiatan yang memberikan paket perjalanan untuk menikmati suatu peristiwa yang disenangi kebanyakan orang. Perjalanan tersebut baik dilakukan secara individu maupun berkelompok dan memiliki tujuan bersenang-senang. Dalam perkembangan bisnis di bidang pariwisata, hal ini menjadi peluang bidang lain yaitu industry. Faktanya Pariwisata banyak mengembangkan mavcammacam industry di berbagai wilayah terutama Indonesia. Meskipun demikian pariwisata bukan bagian dari industry karena dua bidang ini berdiri dan memiliki peran masing-masing. Faktor yang mempengaruhi keterikatan pariwisata dengan industry yaitu keterlibatan individu ataupun kelompok yang melaksanakan perjalanan.

Seperti definisi yang sudah di sampaikan bahwa pariwisata dapat dilakukan individu atau sekelompok orang untuk menikmati peristiwa menyenangkan. Individu atau sekelompok orang tersebut merupakan pelaku pariwisata. Pelaku tersebut adalah wisatawan. Wisatawan melakukan perjalanan memiliki alasan masing-masing. Seperti wisatawan yang datang ke Kota Blitar. Alasan para wisatawan datang ke Kota Blitar memang cukup variatif. Dari seluruh pelosok Indonesia tertarik ke Kota Blitar. Hal itu dikarenakan letak wisata religi/pilgrim makam proklamator Indonesia Ir. Soekarno terletak di ujung utara Kota Blitar. Sehingga selain Sumber daya alam yang tidak ada sama sekali di wilayah kota, jumlah wisatawan inilah yang mempengaruhi program pemerintah Kota Blitar memberdayakan kampung kreatif untuk memberikan tambahan 
kebutuhan aktifitas wisatawan saat mengunjungi Kota Blitar.

Kebutuhan Wisatawan melakukan perjalanan salah satunya faktor kebutuhan Fisik. Seseorang yang melakukan kegiatan sehari-hari dengan rutinitas terstruktur dan monoton cenderung akan merasa bosan dan menginginkan hal baru untuk menyegarkan fisik dan mental. Tidak jarang ada seseorang yang menghabiskan banyak waktu untuk bekerja. Sehingga menetralkan kondisi fisik maupun mental seseorang membutuhkan waktu untuk mengistirahatkan fisknya. Ini sama artinya dengan melarikan diri selama sementara untuk memulihkan fisik yang terlalu lelah. Penawaran paket wisata di Kota Blitar diharapkan dapat menjadi salah satu tujuan seseorang untuk menghilangkan penat. Adanya paket wisata kampung kreatif diharapkan dapat meredakan fisik dan mental yang cukup lelah dengan rutinitas sehari-hari. Sehingga faktor lain yaitu kesehatan dapat terpenuhi juga kebutuhannya.

Beberapa Wisatawan melakukan perjalanan dengan alasan faktor kesehatan tidak jarang merupakan upaya yang diberikan dokter untuk mempercepat proses penyembuhan. Sudah sangat umum ada pada perjalanan wisata menjadi sarana untuk usaha penyembuhan penyakait atau dengan alasan kesehatan. Dokter banyak memberikan saran untuk berwisata di tepi pantai atau di daerah pegunungan agar mendapatkan udara yang lebih segar daripada udara di kota. Faktor kesehatan seseorang juga sangat perlu diperhatikan kondisi fisik jika melakukan perjalanan yang jauh. Dengan adanya kampung kreatif yang berlomba-lomba menjadikan kampung ramah lingkungan dan penghijauan yang maksimal akan menjadi alternatif perjalanan singkat dan hemat untuk wisatawan. Seperti pengolahan tanaman obat untuk penyembuhan beberapa penyakit juga dapat di peroleh dalam paket wisata kampung kreatif yang diberikan Kota Blitar. Selain itu paket kegiatan pariwisata kampung kreatif dapat dilakukan secara bersama-sama dan menyenangkan.

Kegiatan melakukan wisata secara bersama-sama tidak lepas dari kebutuhan manusia sebagai makhluk social, dimana mereka berinteraksi dengan sesama manusia untuk menjalin hubungan. Mereka bertemu dan berkomunikasi satu dengan yang lain.
Menurut Robert Kebutuhan dalam kebersamaan juga dapat masuk pada keinginan seseorang melakukan perjalanan wisata. Dalam kehidupan besosial manusia tidak hidup dalam satu lingkungan saja, ada saatnya mereka berpindah tempat dan bertemu dengan lingkungan yang baru. Perjalanan wisata ini dapat digunakan untuk memanfaatkan kebutuhan bersosialisasi agar mendapatkan lingkungan yang nyaman. Selain itu juga dapat sebagai kesempatan menjalin pertemuan dengan lingkungan yang terdahulu. Kampung kreatif Kota Blitar banyak sekali menawarkan paket wisata yang melibatkan kebersamaan tim. Pada saat melakukan kunjungan wisata dan berkeliling kampung wisatawan secara bersama-sama dapat mengabadikan momen bersama dalam kegiatan tersebut. Interaksi ini sangat menyenangkan untuk wisatawan yang sangat menyukai perjalanan bersama-sama. Sehingga kegiatan yang menyenangkan ini dapat dijadikan imbalan atau penghargaan untuk diri sendiri yang membutuhkan suasana baru dari kegiatan sehari-harinya.

Seseorang tidak hanya dapat menghargai orang lain saja namun sikap menghargai diri sendiri juga sangat dibutuhkan. Diri seseorang dalam kehidupannya pasti menginginkan hal terbaik yang bisa didapatkan atauoun dilakukan. Sehingga atas usaha keras memberikan hal yang terbaik pada diri sendiri inilah yang patut dihargai. Robert menyatakan Penghargaan kepada diri sendiri ataupun orang lain dapat di wujudkan pada kegiatan berpariwisata. Mislakan pada suatu perjalanan kita untuk melaksanakan pertemuan bisnis meningkatkan kualitas diri merupakan sebuah penghargaan. Tidak jarang pada sebuah perusahaan memberikan paket perjalan untuk para karyawan yang berprestasi dalam meningkatkan kualitas perusahaan. Penghargaan ini juga dapat diberikan kepada keluarga yang membutuhkan perjalanan pariwisata yang menyenangkan setelah masing-masing sibuk dengan kegiatan individu. Penghargaan pada diri sendiri merupakan peluang seseorang untuk mengaktualisasi diri. Dimana aktualisasi diri merupakan wujud dari bentuk bersenangsenang. Menggunakan bakat yang dimiliki untuk diaktualisasikan saat melakukan perjalanan wisata termasuk penghargaan 
individu yang dapat dilakukan. Misalnya bakat menggambar, ini dapat dilakukan ketika berlibur di Kampung kreatif yang menawarkan kegiatan melukis.

Pengembangan bakat seseorang adalah upaya menambah keahlian ataupun ilmu pengetahuan yang belum sepenuhnya didapatkan. Menurut Robert melakukan perjalanan adalah salah satu cara menambah cakrawala berfikir seseorang. Rasa ingin tahu dirasakan oleh banyak orang. Sebagai contoh saat wisatawan mengunjungi tempat-tempat kerajinan seperti pembuatan gerabah, alat music kayu dan karya rupa terapan lain akan sangat menyenangkan jika itu dapat dilakukan karena berbeda saat hanya menonton ditelevisi dibandingkan dengan melihat langsung. Sehingga kemampuan apresiasi terhadap keindahan sebuah karya akan muncul dengn sendirinya. Manusia membutuhakan sikap apresiasi terhadap keindahan karena rasa apresiasi dapat meningkatkan rasa puas terhadap pencapaian. Sebagai contoh seseorang yang sangat peduli dengan lingkungan akan merasakan kepuasan saat melihat taman yang bersih, asri dan sejuk. Berwisata di kampung kreatif Kota Blitar kepuasan adalah harapan pengelola saat wisatawan datang untuk melakukan kegiatan. Paket-paket edukasi yang diberikan akan memberikan pengalaman estetika yang mungkin tidak didapatkan di lain kesempatan.

Bisnis pariwisata wajibnya menyadari alasan wisatawan memutuskan untuk berlibur untuk memenuhi beranekaragam kebutuhan yang diinginkannya. Maka untuk membentuk sebuah bisnis pariwisata seperti kampung kreatif yang direncanakan cukup dengan menggunakan pemasaran berdasarkan kebutuhan tersebut. Kaitan dengan bidang pendidikan akan lebih efektif dan banyak orang yang melakukan wisata dikarenakan kebutuhan utama para wisatawan adalah untuk keingintahuan dikarenakan beberapa kegiatan yang belum pernah mereka lakukan. Sehingga paket-paket edukasi akan sangat menguntungkan baik untuk pengelola maupun untuk wisatawan local maupun luar kota.

\section{Kampung Kreatif Kota Blitar}

Kota Blitar terdiri dari 3 kecamatan yaitu Kecamatan Sukorejo, Kecamatan Sananwetan dan Kecamatan Kepanjen kidul. Dari 3 kecamatan tersebut ada 21 kelurahan yang menjadi sasaran program "MAYA JUWITA" (Masyarakat Berdaya Menuju Kota Pariwisata). Masing-masing kelurahan diberikan pembinaan untuk membentuk sebuah kampung kreatif yang dapat dijadikan destinasi wisata Kota Blitar.

Sayangnya hanya ada beberapa Kampung Kreatif yang aktif berdasarkan target jumlah kelurahan. Sekitar ada 10 Kampung kreatif yang sudah menjalankan program paket wisata yang ditawarkan. Termasuk paket wisata pendidikan sesuai konsep dari kampung kreatif terkait. Adapun beberapa Kampung Kreatif yang sudah menerbitkan diri sebagai destinasi wisata antara lain : Kampung Batik turi, Kampung Cyber, Kampung Kendang Sentul, Kampung Mint, Kampung Belimbing, Kampung 3D Bongares, Kampung Nirwana Boclent dan Kampung Bathok.

\section{a) Paket Edukasi Wisata Batik Kembang Turi (Kelurahan Turi)}

Kampung wisata batik kembang turi adalah salah satu kampung kreatif yang berada di Kelurahan Turi, Kecamatan Sukorejo, Kota Blitar. Kampung ini diresmikan pada tanggal 02 oktober 2018. Pusat kegiatan kampung mulai dari gapura masuk kampung Batik hingga ke tempat produksi hanya berjarak 200 meter. Tidak adanya sumber daya alam yang disuguhkan untuk wisatawan sehingga tim yang di support Lurah setempat sepakat untuk mengembangkan sumber daya manusia yang dimiliki. Langkah awal yang dilakukan yaitu berkoordinasi dengan pemerintah terkait tentang program pelatihan yg sudah pernah dilakukan, dan ternyata pelatihan Batik ini yang sering di lakukan warga kelurahan Turi. Potensi inilah yg selanjutnya dikembangkan dan warga semangat untuk mengangkat potensi Batik Kembang Turi sesuai dengan nama kelurahannya sebagai destinasi wisata kelurahan Turi.

Pendidikan sangat mempengaruhi dalam penyusunan paket wisata. Hal ini disebabkan sebagai pembatik pemula tentunya berat untuk bersaing keluar daerah dengan skala yang masih terbatas. Oleh sebab itu langkah awal paket edukasi adalah salah 
satu peluang yang di ambil tim kampung kreatif Batik Kembang Turi.

Paket wisata edukasi Kampung Batik Kembang turi antara lain :

1. Paket batik tulis.

2. Paket batik cap.

3. Paket Pengenalan Batik

4. Paket mewarna batik .

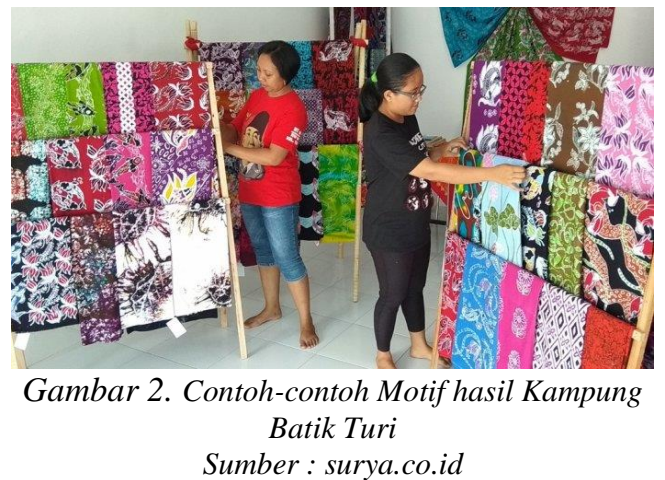

Sasaran wisatawan beraneka ragam, berbagai kalangan mulai tertarik dengan paket yang ditawarkan. Wisatawan sasaran yang pernah mencoba paket edukasi ini antara lain mulai dari TK, SD, SMP, SMA, IBU KADER POSYANDU, ODGJ dan lain-lain. Adapun penyesuaian paket wisata edukasi untuk siswa sekolah dengan menyesuaikan permintaan program outting class. Manfaat melestarikan kebudayaan leluhur sangat mendominasi paket wisata edukasi ini, selain itu dapat meningkatkan perekonomian warga masyarakat sekitar lokasi khususnya.

\section{b) Paket Edukasi Kampung Cyber}

Kampung Cyber merupakan kampung kreatif yang dibentuk pada tahun 2017 lokasi terletak di perumahan BTN ASABRI kelurahan Gedog, Kecamatan Sananwetan Kota Blitar. Kampung ini mulai dibentuk dikarenakan potensi masyarakatnya. Awal mulai pembentukan didasarkan dari keaktifan beberapa pemuda di Kelompok Informasi Masyarakat (KIM) Asabri, kemudian dari kegiatan - kegiatan KIM Asabri yang bergerak di bidang teknologi informasi dengan kegiatan "desiminasi informasi" KIM sendiri dibentuk dari, oleh dan untuk masyarakat. Proses tersebut memberikan banyak potensi yang ada di BTN Asabri, mulai dari kuliner, pengrajin batik, bank sampah dan ketertarikan rekan - rekan dalam pengembangan dan pengelolaan Teknologi Informasi. Potensi - potensi tersebut dikelola dalam bentuk Kampung Kreatif "Kampoeng Cyber" adanya fasilitas market place perlahan - lahan penataan wilayah benar - benar mampu menjadi kampung wisata kreatif dengan mengedepankan "edukasi" terhadap masyarakat, mulai dari pembelajaran pengelolaan teknologi informasi, Membatik, Kuliner dan Pengelolaan dan Manajemen Bank Sampah.

Pendidikan salah satu pengaruh besar dalam pengembangan potensi Kampung Cyber ini. beragam potensi yang ada tentu perlu pengelolaan sehingga dengan adanya pendidikan akan memberikan wacana baru bagi para pelaku usaha. Dengan adanya paketpaket edukasi terhadap produknya tentu akan mempengaruhi pengunjung untuk datang dan belajar, baik itu membatik, membuat web dan mengelolanya, belajar kuliner dan lain sebagainya.

Paket wisata Edukasi Kampung Cyber antara lain:

1. Belajar Coding Program Aplikasi dan Website /Edukasi tentang Teknologi Informasi

2. Belajar Membatik (Jumput, Cap dan Tulis)

3. Belajar Memasak/Kuliner

4. Belajar Mengelola Bank Sampah

5. Belajajar Budaya Wayang Blitarian

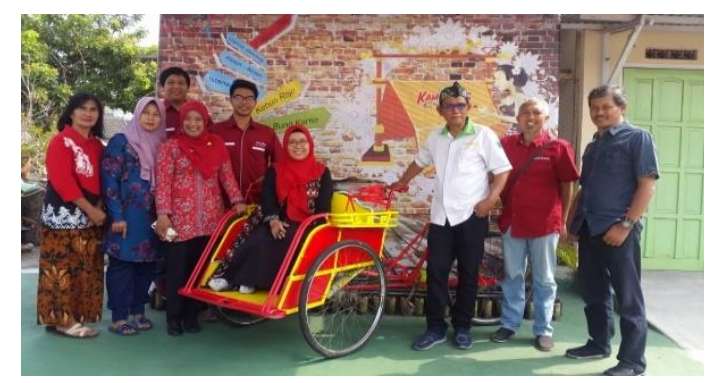

Gambar 3. Area Foto Selfi Kampung Cyber Sumber : Foto Pribadi peneliti

Wisatawan yang mulai mencoba paket wisata Kampung Cyber juga cukup bervariasi, diantaranya Anak - anak usia sekolah dari PAUD hingga perguruan tinggi, 
dan warga masyarakat yang tertarik dengan bidang teknologi informasi, batik, kuliner dan seni budaya. Manfaat memberikan pengalaman dan pembelajaran mampu menarik wisatawan untuk datang mengunjungi Kampung Cyber. Pihak pengelola Kampung cyber sangat menyambut dengan adanya paket edukasi dapat meningkatkan perekonomian masyarakat dan memberikan waktu produktif untuk mereka.

\section{c) Paket Edukasi Kampung Kendang Sentul}

Kampung Kendang Sentul terbentuk pada tahun 2018 terletak di Kelurahan Sentul Kota Blitar. Kampung kreatif ini dibentuk untuk program pemerintah "mayajuwita" yang bertujuan meningkatkan perekonomian warga sekitar. Kampung Kendang Sentul memiliki potensi yaitu adanya kluster industry pembuatan kerajinan kayu dan kerajinan kendang sentul dengan potensi produk unggulan kerajinan kayu kendang sentul. Kluster industry ini membuat pengelola mempunyai ide untuk mengembangkan sector kreatif lain non produk yakni berupa jasa pendidikan/Edukasi.

Adapun Paket Edukasi yang ditawarkan oleh Kampung Kendang Sentul antara lain:

1. paket kunjungan @ 5.000/orang

2. paket kunjungan plus souvenir @ 25.000 / orang

3. paket kunjungan, praktek dan bermain@ 50.000 / orang

Kegiatan Outing class di sejumlah sekolah Kota Blitar dan di luar Kota Blitar mulai memberikan peluang minat wisatawan kampung kreatif Kendang Sentul ini. Mulai dari siswa PAUD sampai Perguruan Tinggi pernah mencoba paket wisata Edukasi ini. Tidak jarang pula berbagai perkumpulan dan Pegawai Pemerintah melakukan kunjungan dan mencoba paket edukasi yang disediakan pengelola.

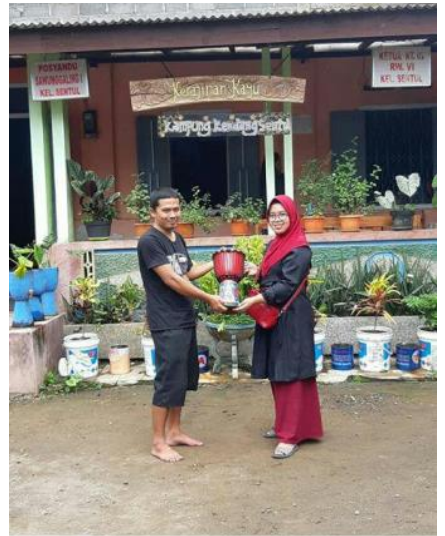

Gambar 4. Hasil Painting Body Jinbe paket wisata Kampung Kendang Sumber : Foto Pribadi peneliti

Paket edukasi di Kampung Kendang Sentul memberikan manfaat untuk wisatawan mengenal budaya local dan memberikan pengalaman berkarya. Sedangkan untuk pengelola dapat menambah perekonomian dan memperbanyak relasi serta memberikan rasa kebanggaan tersendiri terhadap kearifan lokal yang mereka kembangkan.

\section{d) Paket Edukasi Kampung Mint Blitar}

KMB (Kampung Mint Blitar) terletak di kelurahan Pakunden Kota Blitar dibentuk pada 14 April 2018. Kampung Mint Blitar terbentuk sejak keputusan pemilihan RW 02 sebagai Lokasi Kunjungan Tim Verikasi Kelurahan Berseri Provinsi yang merupakan RW tambahan. Penetepan ini membuat masyarakat RW 2 bersemangat menghijaukan lingkungan sekitar. Selanjutnya muncul komitmen warga untuk membudidayakan tanaman mint sebagai tanaman utama dalam proses penghijauan lingkungan mereka.

Gerakan budidaya tanaman mint diprakarsai ibu-ibu KWT (Kelompok Wanita Tani) Kirani. Budidaya tanaman Mint di Lingkuangan RW 02 terus dikembangkan dan berhasil diolah menjadi beberapa produk Mint. Kampanye memperkenalkan manfaat yang dapat diperoleh dari Mint sebagai salah satu alternative obat herbal yang khas juga menjadi faktor menambah semangat warga sekitar. Pembentukan Kampung Mint Blitar semakin mengembangkan menunjukkan eksistensi dengan menarik masyarakat untuk mengenal lingkungan RW 2. Hal itu diwujudkan dengan dibuatlah papan identitas kawasan "Selamat Datang di Kampung Mint 
Bebas Masuk Angin “ di gapura jalan masuk di lingkungan RW 02. Dengan demikian warga RW 02 yakin dengan potensi yang dimiliki sehingga dibentuklah kampung kreatif untuk mendukung program "Mayajuwita" yang dicanangkan pemerintah Kota.

Pada saat kunjungan tim verivikasi lapangan dari DLH Kota Blitar, warga menyuguhkan berbagai makanan dan minuman 'teh mint' produk ini yang menjadi pembahasan saat itu. Minuman olahan mint mempunyai kekhasan dalam hal rasa, dan merupakan obat alternative yang mempunyai banyak manfaatnya, antara lain obat masuk angin, magh, batuk anti inflamasi dan masih banyak lainnya.

Terbentuknya kampong-kampung kreatif yang ada di Kota Blitar, membuat tim merasa tertantang untuk menjadi bagian didalamnya. pengembangan potensi lingkungan yang sudah tertata, masyarakat luas juga perlu diedukasi dengan obat obat herbal agar tidak tergantung dengan obat kimia. Menurut warga RW 2 menanam berbagai macam jenis tanaman mint membuat tanaman itu dapat dijadikan produk unggulan, selain itu guna menambah nilai hasil tanam. Tujuan yang lain yaitu warga RW 02 ingin meningkatkan kesehatan masyarakat, kesehatan lingkungan dan sekaligus wahana edukasi bagi warga dan masyarakat secara umum.

Adapun paket wisata edukasi yang ditawarkan Kampung Mint Blitar antara lain:

1. Pengunjung Bebas (tanpa guide)

Di area KMB alur pengujung disiapkan mulai dari pintu masuk sebelah barat, atau setelah berkunjung di RTH, menuju Central Mint, lanjut keliling kampung sesuai arah yang dipasang dilokasi.

2. Paket 1 , berbayar Rp 10.000 ,- ( minimal 20 orang)

- Keliling KMB dengan guide badut

- Edukasi menanam mint

- 1 biibit mint gratis

- Minuman mint gratis

3. Paket 2, berbayar Rp 15.000,- (minimal 20 orang)

- Keliling KMB oleh Badut

- Edukasi menanam mint

- Edukasi olahan sampah

- Fun Games

- 1 biibit mint gratis

- Minuman mint gratis

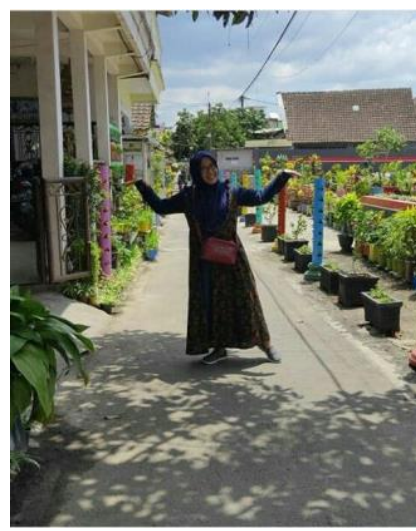

Gambar 5. Suasana Kampung Mint Blitar Sumber : Foto Pribadi peneliti

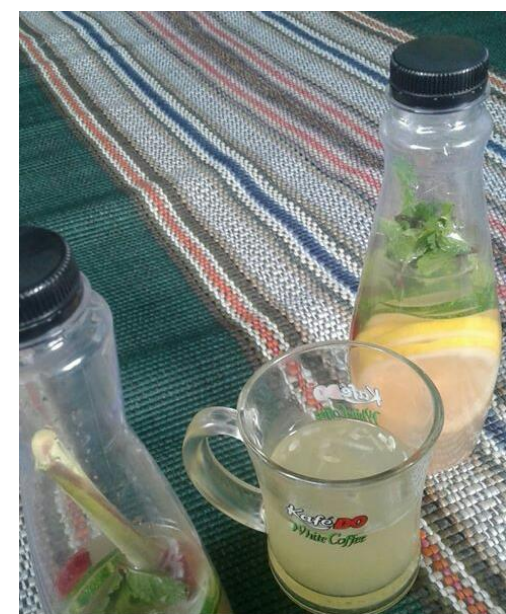

Gambar 6. Infus Water Salah satu produk andalan kampung Mint Blitar

Sumber : Foto Pribadi peneliti

Adanya berbagai paket memudahkan masyarakat untuk menentukan edukasi yang diinginkan, sesuai tarif ataupun menyesuaikan kebutuhan. Sasaran wisatawan disegala usia memberikan peluang untuk semakin meningkatkan perekonomian warga. Selain itu memberikan edukasi tentang tanaman herbal yang sangat bermanfaat untuk wisatawan.

\section{e) Paket Edukasi Kampung 3D Bongares}

Kampung 3D Bongares merupakan salah satu kampung kreatif yang terletak di tengah Kota Blitar. Seperti namanya Bongares (Bocah Ngarep Polres) yang berarti "anak depan polres" merupakan penegasan letak lokasi kampung kreatif ini yang berada tepat di depan POLRESTA Blitar. Berdiri pada 12 April 2017 Kampung 3D Bongares terbentuk dikarenakan faktor kesempatan untuk mengikuti lomba kampung berseri tingkat Provinsi. Pada saat itu warga memilih untuk 
menghias kampung mereka yang cukup sempit dengan jalanan yang hanya dapat dilewati motor. Lukisan 3D mereka pilih untuk mendominasi keindahan pada kampung tidak lepas dari potensi yang ada di kampung tersebut. Banyaknya anak muda yang pandai melukis menjadikan kampung 3D Bongares sangat menarik dikunjungi wisatawan.

$$
\text { Kesempatan mengenalkan }
$$

keterampilan seni lukis untuk wisatawan membuat pengelola semangat memberikan paket wisata edukasi pada kampung kreatif yang telah berhasil mereka bentuk ini. Keterampilan dalam seni lukis bukan satusatunya yang mereka kembangkan dalam kampung kreatif ini. Beberapa warga yang memiliki keterampilan menanam buah nanas dan tanaman sayuran memberikan peluang UMKM mendukung perkembangan destinasi wisata kampung kreatif ini.

Paket wisata edukasi yang ditawarkan oleh Kampung 3D Bongares antara lain:

1. Belajar seni melukis $3 \mathrm{D}$

2. Belajar menanam tanaman sayur dalam polybag

3. Belajar mengolah bermacam macam kripik buah dan sayur.

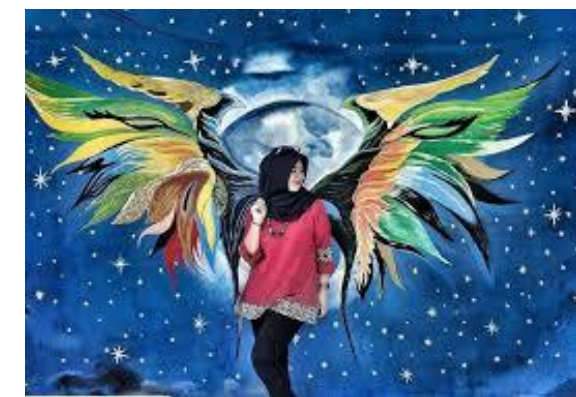

Gambar 7. Salah satu area foto favorit kampung $3 D$ Sumber: datawisata.com

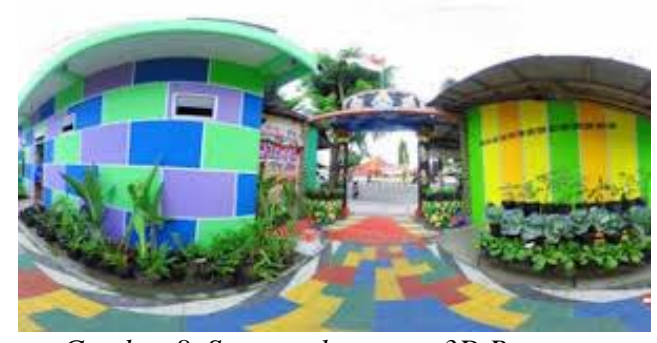

Gambar 8. Suasana kampung 3D Bongares Sumber: koranmemo.com perguruan tinggi. Selain itu wisatawan local dari berbagai organisasi dan pemerintahan mulai melirik kampung kreatif 3D bongares untuk kegitan liburan mereka. Pengalaman menanam sayuran dan mengolah kripik buah juga sangat menyenangkan para wisatawan. Dengan otomatis perekonomian warga setempat juga meningkat.

\section{f) Paket Wisata Edukasi Kampung Nirwana Boclent.}

Kampung Niwana Boclent berdiri mulai tahun 2018. Menurut ketua RW sebagai ketua penggerak, kampung ini dibentuk saat melihat potensi warganya yang dapat digerakkan untuk mengikuti lomba lomba Perencanaan kampung kreatif yg diselenggarakan Bapeda kota Blitar. Potensi ini terlihat karena wilayah lokasi berdekatan dgn Klenteng Poo An Kiong dan secara historis tradisi dan budaya klenteng sangat melekat dgn kehidupan masyarakat. Mulai dari kesenian Barongsai, wayang Poo The Hi, dan musik mandarin yang sudah menjadi bagian budaya masyarakat. Sebagian besar masyarakat dapat menguasai kesenian tersebut. Sehingga dengan potensi ini diharapkan banyak masyarakat berkeinginan belajar memainkan kesenian Tiong Hua. Dengan demikian kampung akan selalu dapat melestarikan kesenian yang tidak sembarang orang dapat memainkannya. Peran pendidikan dalam pengembangan Kampung Nirwana Boclent sangat mempengaruhi proses pengmbangan promosi yang ditawarkan. Adanya paket edukasi belajar bermain kesenian Tiong Hua memberikan ciri khas kampung kreatif ini. Karena merupakan satusatunya kampung kreatif yang mengusung tema Tiong Hua.

Tersedianya tenaga ahli dalam kesenian Tiong Hua memberikan peluang Kampung Nirwana Bocklent menawarkan beberapa paket edukasi yaitu :

1. Edukasi Kesenian Barongsai

2. Edukasi musik mandarin

3. Edukasi pembuatan barongsai dan wayang Poo The Hi

Sasaran wisatawan sangat bervariasi

mulai dari usia sekolah PAUD sampai 


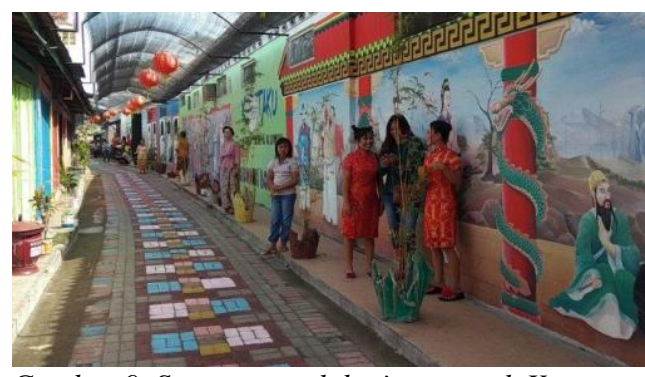

Gambar 9. Suasana setelah pintu masuk Kampung NIrwana Boclent

Sumber: tribunnews.com

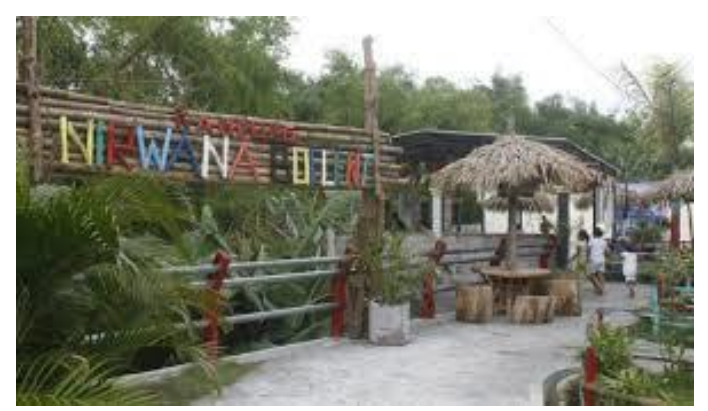

Gambar 10. Taman pinggiran Sungai yang sebelumnya TPS

Sumber: genpi.com

Wisatawan yang datang ke kampung ini cukup variatif adanya taman bermain di pinggiran sungai membuat menarik anak-anak untuk datang mengunjungi kampung kreatif ini. Selain anak sekolah, wisatwan domestic juga sering menghabiskan kegiatan di taman kampung kreatif ini. Adapun kegiatan paket wisata yang telah ditawarkan para etnis Tiong Hua sudah banyak yang datang untuk belajar ke kampung ini.

\section{g) Paket Wisata Edukasi Kampung Bathok.}

Kampung batok berdiri pada tanggal 15 febuari 2009 memiliki pontensi unik dalam mengelola kampung kreatif ini. Terletak di kelurahan Tanjungsari Kampung Batok memiliki wilayah yang cukup strategis sebagai tujuan wisata edukasi. Selain untuk mendukung program pemerintah kota "Maya Juwita" warga Kampung Batok ingin meningkatkan pendapatan warga sekitar. Sehingga dengan memaksimalkan dua tempat pengolahan limbah kelapa di wilayah ini membuat warga antusias membuat Kampung Batok menjadi lebih diminati wisatawan. Menurut Nurcholis selaku ketua pengelola Kampung Batok pendidikan atau edukasi dalam penentuan paket wisata di Kampung Bathok sangatlah mendominasi karena dengan memberikan pembelajaran kreativitas akan meningkatkan minat kunjungan wisatawan. Selain itu juga secara tidak langsung akan meningkatkan ekonomi warga sekitar akan produk hasil olahan limbah kelapa ini. Adapun paket wisata edukasi untuk masing-masing individu yang ditawarkan Kampung Bathok antara lain:

1. Manggar (5rb) paket edukasi apresiasi dengan berkeliling melihat proses produksi limbah kelapa.

2. Bluluk (10rb) paket edukasi apresiasi melihat proses produksi dan pembuatan gelang

3. Degan (15rb) paket edukasi apresiasi melihat proses produksi, pembuatan gelang dan mendapatkan snack olahan kelapa.

4. Kambil (20rb) paket edukasimelihat proses produksi, edukasi pembuatan gelang dan mendapatkan snack olahan kelapa serta makan siang.

5. Dan Paket edukasi lainnya sesuai permintaan pengunjung.

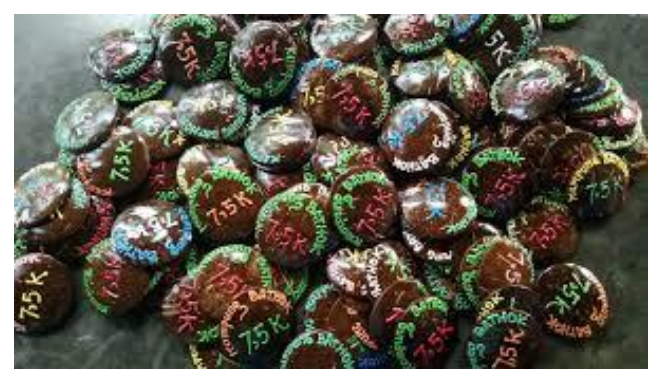

Gambar 11.

Gantungan kunci hasil olahan Kampung Bathok Sumber: jatim.net

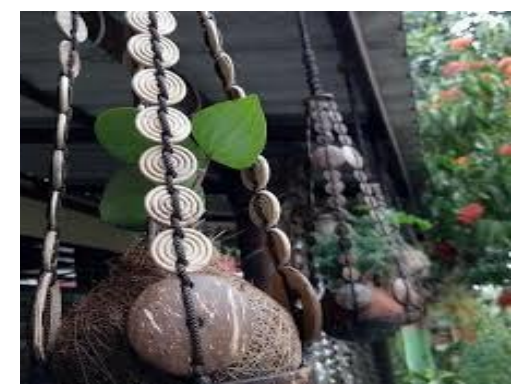

Gambar 12. Teknik Menanam Cocodama yang sedang dikembangkan Kampung Bathok Sumber: picuki.com

Mentransferkan ilmu pengetahuan tentang pengolahan limbah kelapa ini memberikan nilai ekonomis pada warga 
sekitar. Sasaran wisatawan cukup bervariasi namun lebih di dominasi oleh anak sekolah yang melaksanakan outing class sebagai salah satu program dari sekolah.

\section{h) Kampung Belimbing Karangsari}

Kampung Belimbing Karangsari terletak di kelurahan Karangsari Kota Blitar. Menurut Kepala Kelurahan Karangsari fasilitas yang ditawarkan kampung wisata Belimbing Karangsari, akan terus berusaha mengembangkan jenis tanaman buah belimbing. Belimbing di Karangsari kualitasnya istimewa. Dikarenakan bentuknya besar dan rasanya lebih manis dan segar. Potensi kampung Belimbing Karangsari didukung dengan adanya pengembang agrowisata tanaman belimbing yang memiliki lahan 5 hektar yang terletak hanya beberapa ratus kilometer saja dari Kampung Belimbing. Pengembang ini menggandeng warga sekitar untuk membudidayakan blimbing karena setiap rumah di karangsari memiliki pohon belimbing. Maka sudah sangat pantas jika wilayah ini diberi nama kampung Belimbing. Total lahan jika digabung dengan pemilik agrowista dan kampung belimbing sekitar 25 hektar. Kerjasama ini disambut baik oleh warga yang kemudian mengembangkan kampung belimbing dengan memberikan paket edukasi yaitu:

1. Edukasi kuliner olahan belimbing

2. Edukasi budidaya belimbing

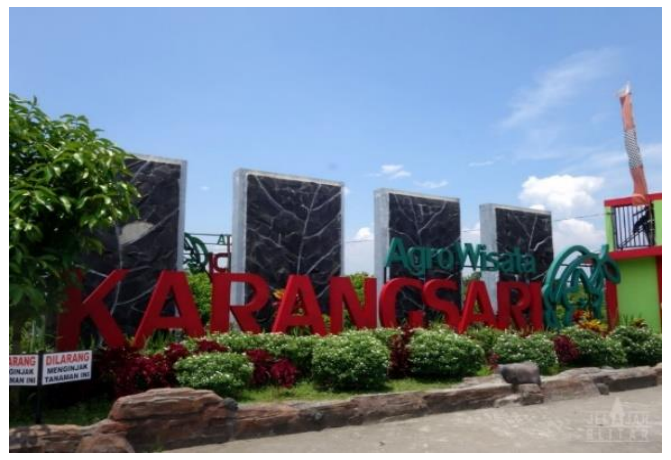

Gambar 13. Agrowisata Belimbing Karangsari Sumber: mblitar.net

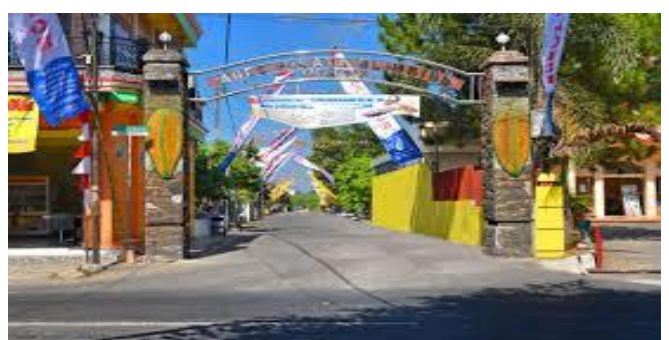

Gambar 14. Pintu masuk Kampung Belimbing Karangsari

Sumber: wordpress.com

Sasaran wisatawan sangat beragam karena lokasi ini banyak diminati semua kalangan. Terlebih letak agrowisata belimbing karangsari terletak dipinggir jalan antar Kota Blitar dan Tulungagung maka akan mudah dikunjungi untuk sekedar mampir membeli oleh-oleh serta dapat sebagai lahan promosi kampung Belimbing yang berada tidak jauh dari lokasi Agrowisata Belimbing Karangsari. Tabel 1. Data Paket Edukasi Pada Kmpung Kreatif Kota Blitar

\begin{tabular}{llc}
\hline No & \multicolumn{1}{c}{ Kampung Kreatif } & $\begin{array}{c}\text { Status Paket } \\
\text { Wisata } \\
\text { Edukasi }\end{array}$ \\
\hline 1 & Kampung Batik Turi & $\sqrt{ }$ \\
2 & Kampung Cyber & $\sqrt{ }$ \\
3 & Kampung Kendang Sentul & $\mathbf{V}$ \\
4 & Kampung Mint Blitar & $\mathbf{V}$ \\
5 & Kampung 3D Bongares & $\sqrt{ }$ \\
6 & Kampung Nirwana Boclent & $\sqrt{ }$ \\
7 & Kampung Bathok & $\sqrt{ }$ \\
8 & Kampung Belimbing Karangsari & $\mathbf{V}$ \\
9 & Kampung Opak Gambir & - \\
10 & Kampung Kuliner & - \\
\hline
\end{tabular}

Dalam Tabel terlihat ada 8 dari 10 yaitu mencapai prosentase $80 \%$ Kampung Ktreatif yang aktif di Kota Blitar menyertakan paket edukasi untuk mengembangkan sebagai destinasi Kampung Wisata. Tersisa kampung kuliner dan kampung Opak Gambir dimana kedua kampung ini masih belum menyertakan paket edukasi pada pengembangan kampung kreatifnya sehingga pemanfaatan sebagai kampung wisata tdk dapat dimaksimalkan.

Faktor yang menyebabkan kampung kuliner tidak lebih berkembang daripada kampung lainnya yaitu hanya menggerakkan warga sepanjang jalan utama Kelurahan Kauman untuk berjualan di pinggir jalan. Hal ini yang menyebabkan warga kurang tertarik jika hanya disajikan wisata kuliner tanpa ada branding sebagai kampung wisata yang memiliki konsep. Sehingga penikmat kuliner hanya menganggap para warga yang berjualan 
adalah penjual biasa yang berdagang dipinggir jalan.

Kampung Opak Gambir berbeda dengan Kampung Kuliner. Dalam sebuah artikel di Harian Surya Malang juga menyebutkan Kampung kreatif ini sangat maju dalam pengembangan produk yaitu Opak Gambir. Dimana inovasi pengemasan untuk snack Opak Gambir dapat digunakan sebagai souvenir segala macam hajatan di local Kota Blitar bahkan sampai di luar Kota Blitar. Majunya dalam bidang UMKM (Usaha Mikro, Kecil, Menengah) ini faktanya membuat pengelola Kampung Opak Gambir merasa cukup puas. Akan tetapi dalam hal pengenalan kampung mereka tidak melakukannya secara maksimal. Sehingga Kampung Opak Gambir hanya berfungsi sebagai pusat pembuatan dan pengemasan produk Opak Gambir belum adanya konsep branding sebagai Kampung wisata yang dapat ditawarkan ke masyarakat luas menyebabkan kampung ini belum memiliki wisatawan seramai kampung kreatif lainnya.

\section{Kesimpulan}

Penelitian peran pendidikan dalam penentuan paket wisata menjadikan kampung kreatif menemukan dampak positif yang cukup baik. Faktanya $80 \%$ hasil survey beberapa kampung kreatif ada 8 dari 10 kampung kreatif di Kota Blitar menyertakan paket edukasi yang menjadi andalan untuk memberikan peluang peningkatan ekonomi warga sekitar kampung. Sekitar Dukungan pemerintah seperti perangkat desa, Dinas Kebudayaan dan Pariwisata serta Pemerintah Kota Blitar juga memiliki bagian dalam mengembangkan potensi kampung kreatif ini. Dengan mengadakan perlombaan perencanaan kampung kreatif sampai perlombaan kampung kreatif yang telah terbentuk. Dengan proses pendampingan yang konsisten mereka kompak mengembangkan Kota Blitar membentuk kampung kampung kreatif melalui kreatifitas masyarakatnya.

\section{References}

[1] Adiakurnia, Muhammad Irzal. 2019. "Bangga! Indonesia Raih Juara Inovasi
Wisata UNWTO di Spanyol". Diakses taggal 29 Januari 2020 dari : Kompas.com https://travel.kompas.com/read/2018/0 1/18/180111027/bangga-indonesiaraih-juara-inovasi-wisata-unwto-dispanyol?page $=$ all.

[2] Amalia, Sonya dkk. 2019. Panduan Wisata Edukasi Desa Wisata Jernih Kabupaten Sarolangun. Yugyakarta: DeePublish.

[3] Biroli, Alfan. 2015. RASIONALITAS WISATAWAN WISATA PILGRIM (Studi Fenomenologi Terhadap Wisatawan Di Kawasan Wisata Pilgrim Desa Gunungpring, Kecamatan Muntilan, Kabupaten Magelang). Surakarta: Jurnal Analisa Sosiologi Oktober 2015, 4(2): $98 \quad-114$ Universitas Sebelas Maret.

[4] Cokroaminoto. 2014. Metodologi Penelitian Kualitatif. Diakses taggal 29 Januari 2020 dari: http://www.menulisproposalpenelitian. com/2011/01/metodologi-penelitiankualitatif.html.

[5] Darsono. 2005. Pengertian Desa. Diunduh tanggal 10 Maret 2014 dari: http://desasentonorejo.wordpress.com/ bab-ii/

[6] Gunn, Clare A. 2002. Tourism Planning. New York City: Taylor and Francis

[7] Inskeep, Edward. 1991. Tourism Planning: An Integrated Sustainable Development

[8] Mill, Robert Christie. 2000. The Tourism International Business. Jakarta: PT. Raja Grafindo Persada.

[9] Moustakas, Clark E. 1994. Phenomenological Research Methodes. United States of America: Sage Publication

[10] Ricoeur, Paul. Teori Interpretasi Memahami Teks, Penafsiran dan Metodologinya. Jogjakarta: IRCiSoD

[11] Suwena, I Ketut. 2017. Pengetahuan Dasar Ilmu Pariwisata. Denpasar: Pustaka Larasan

[12] Yoeti, Oka. 1996. Pengantar Ilmu Pariwisata. Bandung Penerbit Angkasa 